\title{
Perancangan Desain Logo "R3-Viora" sebagai Identitas Baru UKM Viora Collection, Tanggulangin, Sidoarjo
}

\author{
Choirul Anam1, Alfan Nur Rochman ${ }^{2}$, Achmad Fauzi $^{3}$, Ayu Nindyapuspa ${ }^{4}$, Shah Khadafi ${ }^{5}$ \\ Jurusan Desain Produk ${ }^{1,2,3}$, Lingkungan ${ }^{4}$, Sistem Komputer ${ }^{5}$ \\ Institut Teknologi Adhi Tama Surabaya - Jl. Arief Rahman Hakim 100, Surabaya \\ Email : choirul.despro@itats.ac.id ; No. HP : 083857000385
}

\begin{abstract}
ABSTRAK
UKM Viora adalah salah satu Usaha Kecil Menengah yang berlokasi di Tanggulangin, Sidoarjo. UKM ini bergerak dibidang pembuatan produksi tas, dompet dengan menggunakan bahan daur ulang dari kantong semen dan mengusung tema produk yang ramah lingkungan. Dalam perjalanan usahanya, UKM Viora kesulitan dalam mengembangkan nilai produknya, hal ini disebabkan karena faktor yang paling penting dalam sebuah usaha yaitu identitas, dimana identitas dalam hal ini harus diakui, terdaftar dan dikenal oleh masyarakat. Identitas tersebut terdapat pada sebuah logo dan merupakan nama yang dipakai UKM Viora dalam memasarkan produknya dan terkendala tidak diterima nama dan logonya saat mendaftar dikarenakan ada UKM yang memiliki nama dengan pengucapan yang sama, sehingga efeknya logo dan merknya tidak bisa disematkan atau diaplkiasikan produk UKM VIORA. Pengabdian ini dilakukan untuk mendampingi UKM Viora dalam perancangan logo dan nama baru untuk identitas usahanya sehingga bisa terdaftar dan dapat diterapkan kedalam setiap produknya. Disamping itu juga pendampingan pembuatan logo ini, bertujuan meningkatkan daya saing dan nilai jual produk - produk yang dihasilkan. Hasil dari pengabdian ini menunjukkan bahwa logo dan nama yang ditawarkan memiliki berbagai macam variasi dan jenisnya serta konsep dan maksud dari setiap logo yang dibuat, sehingga terpilih desain logo yang sesuai kebutuhan UKM Viora untuk dijalankan dan diaplikasikan kedalam setiap produknya. Logo yang sudah terpilih akan diaplikasikan ke berbagai macam media yang dibutuhkan sebagai kebutuhan awal yaitu stempel. Hasil lebih lanjut menunjukkan bahwa logo dapat diaplikasikan dalam bentuk label, dengan salah satu tekniknya menggunakan laser grafir pada media kulit sintetis dengan ukuran yang diminta oleh UKM Viora.
\end{abstract}

Kata Kunci : perancangan logo; identitas baru; UKM Viora

\section{ABSTRACT}

UKM Viora is one of the UKM in Tanggulangin, Sidoarjo. This UKM is engaged in the production of bags, wallets using recycled materials from cement bags and carries the theme of products that are environmentally friendly. In the course of its business, UKM Viora has difficulty in developing the value of its products, this is because the most important factor in a business is identity, where identity in this case must be recognized, registered and known by the public. The identity is contained in a logo and is the name used by UKM Viora in marketing its products and is constrained from not being accepted by name and logo when registering because there are Sames that have names with the same pronunciation, so the effect of the logo and brand cannot be pinned or diplomatic in every product made by UKM VIORA.This service was carried out to assist UKM Viora in designing a new logo and name for its business identity so that it can be registered and can be applied to each of its products. Besides that, it is also mentoring the creation of this 
logo to improve the competitiveness and selling value of the products produced.The results of this service show that the logo and name offered have various variations and types as well as the concepts and intentions of each logo that is made, so that the logo design that is most suitable for the needs of UKM Viora is chosen and applied to each product. The logo that has been selected will be applied to various types of media needed as initial requirements, namely stamp. Further results show that the logo can be applied in the form of labels, with one technique using laser engraving on synthetic leather media of the size requested by UKM Viora.

\section{Keywords : logo design; new identity; UKM Viora}

\section{PENDAHULUAN}

Tanggulangin merupakan daerah yang terletak $9 \mathrm{~km}$ dari pusat kota Sidoarjo. Daerah ini merupakan salah satu sentra penghasil kerajinan kulit olahan yang dijadikan dompet, tas, dan alas kaki berupa sepatu dan sandal. Pusat kerajinan tas dan dompet ini sudah ada sejak tahun 1960. Salah satu UKM membuat kerajinan tas yang berada di Tanggulangin adalah UKM Viora. UKM ini merupakan UKM yang bergerak dibidang pembuatan produksi tas, dengan menggunakan bahan daur ulang yaitu kantong semen. Produk dari UKM Viora ini mengusung tema produk Eco Friendly atau produk yang ramah lingkungan. Produk-produk dari UKM Viora tersebut diproses dengan menggunakan bahan-bahan yang alami, dan juga tidak merusak alam. Dikutip dari Jurnal Rekarupa Anam, dkk (2018), visi dari UKM Viora adalah menciptakan produk-produk yang Eco Friendly, dan memiliki nilai jual, dan estetis dalam peningkatan produk dari material daur ulang [1].

Dalam menjalankan usahanya, UKM Viora memerlukan logo sebagai identitas UKM tersebut. Selain menjadi identitas sebuah usaha, logo merupakan cerminan visi dan misi dari sebuah usaha, atau institusi. Dalam hal ini UKM Viora sebelumnya sudah memiliki logo yang sudah dibuat, namun mendapat penolakan saat didaftarkan sebagai merk ke Kemenkumham (Kementerian Hukum dan Hak Asasi Manusia Republik Indonesia), penolakan tersebut didasarkan karena terdapat merk yang sebelumnya sudah terdaftar dengan pengucapan yang sama dengan merk "Viora" yaitu "Fiyora", sehingga UKM VIORA ingin merubah nama usahanya namun tidak ingin melepas kata atau merk VIORA karena para konsumen sudah banyak yang mengenal merk tersebut.

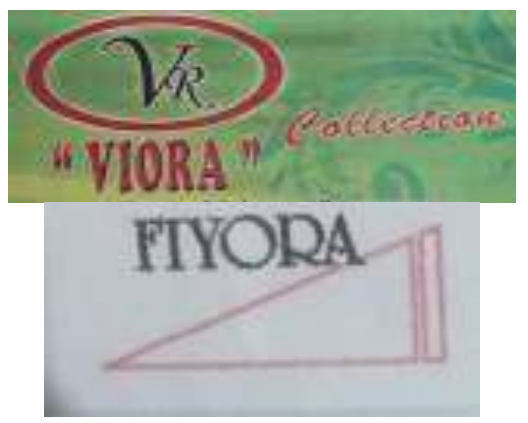

Gambar 1. Logo dari UKM VIORA (Atas), Logo lain yang terdaftar FIYORA (Bawah)

Selain mendapat penolakan mengenai pendaftaran merk, kendala lain yang dialami UKM Viora adalah tidak berani menyematkan logo yang dimilikinya berupa label kedalam produk yang selama ini diproduksinya, baik itu 
Tas, Dompet, Souvenir, dan lain sebagainya sehingga rawan produk tersebut untuk ditiru oleh pengusaha atau UKM yang lain.

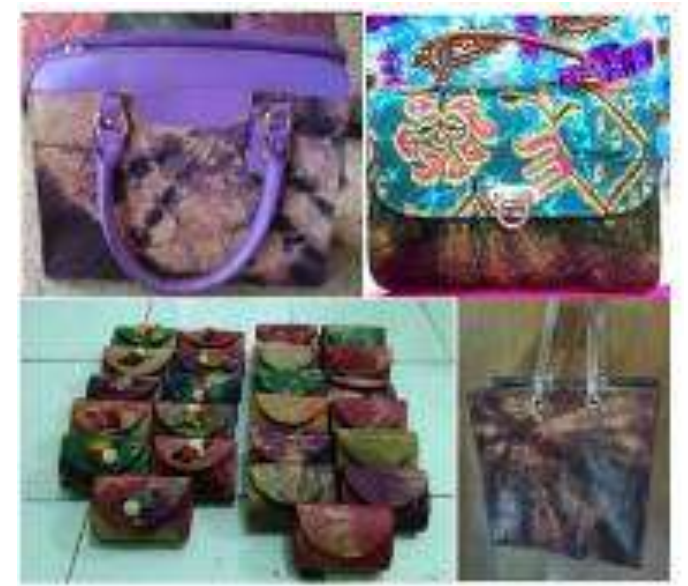

Gambar 2. Produk - produk yang diproduksi oleh UKM Viora

Berdasarkan permasalahan diatas, UKM Viora menginginkan sebuah logo dan nama baru yang menarik, komunikatif, dan memiliki ciri khas sebagai identitas usahanya yang dapat meningkatkan nilai produksi dan kualitas. Dengan demikian dapat dirumuskan bagaimana membuat perancangan desain logo dan nama yang sesuai kebutuhan UKM Viora yang diterapkan dalam bentuk kegiatan Pengabdian melalui pendampingan dan konsultasi.

Dari rumusan masalah yang ditentukan, tujuan program pengabdian adalah membuat dan merancang logo dan nama baru yang menarik, komunikatif, dan memiliki ciri khas sesuai dengan keinginan Pemilik UKM Viora

\section{Unsur Desain}

\section{- Warna}

Warna dapat didefinisikan secara objek/fisik sebagai sifat cahaya yang dipancarkan, atau secara subjektif/psikologis sebagai bagian dari pengalaman indera pengelihatan. Tanpa disadari warna dapat mempengaruhi psikologis manusia. Berikut adalah simolisasi warna dan juga karakternya :

Tabel 1 Karakter Warna

\begin{tabular}{|c|c|c|}
\hline No. & Warna & Keterangan \\
\hline 1. & Kuning & $\begin{array}{l}\text { Warna kuning merupakan } \\
\text { warna cerah yang } \\
\text { mempunyai karakter } \\
\text { warna emosional yang } \\
\text { menggerakkan energi dan } \\
\text { keceriaan dan } \\
\text { kemewahan. Warna } \\
\text { kuning juga } \\
\text { melambangkan } \\
\text { keagungan kemewahan, } \\
\text { kejayaan, kemegahan, } \\
\text { dan, kemulian. }\end{array}$ \\
\hline 2. & Merah & $\begin{array}{l}\text { Warna merah } \\
\text { mengambarkan karakter } \\
\text { yang kuat, marah, berani, } \\
\text { bahaya, positif, agresif, } \\
\text { kekejaman, kesadisan, } \\
\text { panas. }\end{array}$ \\
\hline 3. & Biru & $\begin{array}{l}\text { Warna biru } \\
\text { mengambarkan karaterter } \\
\text { pasif, sayu, sendu, tenang }\end{array}$ \\
\hline 4. & Hijau & $\begin{array}{l}\text { Warna hijau merupakan } \\
\text { warna yang } \\
\text { menggambarkan hijaunya } \\
\text { alam, tumbuhan, dan juga } \\
\text { sesuatu yang hidup dan } \\
\text { berkembang. }\end{array}$ \\
\hline 5. & Hitam & $\begin{array}{l}\text { Warna hitam identik } \\
\text { dengan warna yang } \\
\text { menggambarkan } \\
\text { kegelapan, dan misterius, } \\
\text { malapetaka, keburukan } \\
\text { dan ilmu sihir. Dalam } \\
\text { psikologi warna, hitam } \\
\text { merupakan warna yang } \\
\text { menggambarkan } \\
\text { keagungan, kemakmuran, } \\
\text { kecangihan, dan juga } \\
\text { warna yang independent. }\end{array}$ \\
\hline
\end{tabular}

Sumber : Nugroho, 2015 
- Garis

Menurut Nugroho (2015) garis merupakan elemen dasar, yang terbentuk dari titik yang membentuk goresan. Garis dibagi menjadi tiga jenis yaitu :

a. Garis lurus, adalah garis menghubungkan terpendek antara dua titik yang tidak bertepatan.

b. Garis lengkung datar, garis yang sama sekali tidak mempunyai bagian lurus atau menyiku dan semua titik-titiknya terletak pada sebuah bidang datar.

c. Garis lengkung ruang, garis lengkung yang terletak pada ruang. [2]

\section{- Logo}

Menurut Sularko dkk. (2008) logo bisa diibaratkan dengan wajah. Setiap orang bisa dengan mudah dikenali antara satu dengan yang lain hanya dengan melihat wajah. Begitu juga halnya dengan logo. Logo merupakan sebuah visi penyampaian citra positif melalui sebuah tampilan sederhana dalam bentuk simbol. Logo atau corporate identity atau brand identity adalah sebuah tanda yang secara langsung tidak menjual, tetapi memberi suatu identitas sebagai alat pemasaran yang signifikan, bahwa logo mampu membantu membedakan suatu produk atau jasa dari kompetitornya. [3]

\section{- Jenis Logo}

Logo adalah bagian identitas yang bersifat fisik, sehingga acap disebut dengan visual identity. Visual identity ini diharapkan dapat memberi makna yang universal melintas batas geografis dan budaya. Jadi mendesain logo tidak dapat lagi hanya sekedar imajinasi. Menurut John Murphy \& Michael Rowe, jenis logo terbagi atas 7 yaitu :
Tabel 2. Jenis Logo

\begin{tabular}{|c|c|c|}
\hline No. & $\begin{array}{l}\text { Jenis Logo dan } \\
\text { Penerapan }\end{array}$ & Keterangan \\
\hline 1. & $\begin{array}{l}\text { Name only } \\
\text { Logos } \\
\text { SONY }\end{array}$ & $\begin{array}{l}\text { Logo yang diambil } \\
\text { dari nama produk } \\
\text { tersebut. Logo jenis ini } \\
\text { merupakan jenis } \\
\text { logotype. Logo ini } \\
\text { mertujuan memberi } \\
\text { pesan langsung kepada } \\
\text { konsumen. }\end{array}$ \\
\hline 2. & $\begin{array}{l}\text { Initial L } \\
\text { Logos }\end{array}$ & $\begin{array}{l}\text { Logo yang terbuat dari } \\
\text { huruf awal atau inisial } \\
\text { dari nama produk, atau } \\
\text { singkatan dari nama } \\
\text { perusahaan. }\end{array}$ \\
\hline 3. & iative & $\begin{array}{l}\text { Logo yang bebas, } \\
\text { dimana logo jenis ini } \\
\text { tidak memuat nama } \\
\text { produk, tetapi } \\
\text { memiliki asosiasi } \\
\text { dengan nama, atau } \\
\text { produk. }\end{array}$ \\
\hline 4. & $\begin{array}{l}\text { Allusive Logos } \\
\text { Alitalia }\end{array}$ & $\begin{array}{l}\text { Logo yang bersifat } \\
\text { kiasan, atau } \\
\text { penyederhanaan } \\
\text { gambaran dari sebuah } \\
\text { produk tersebut. } \\
\text { seperti logo Mercedes } \\
\text { Benz yang terdiri dari } \\
\text { bentuk bintang segitiga } \\
\text { yang merupakan } \\
\text { representasi dari } \\
\text { sistem kemudi mobil. }\end{array}$ \\
\hline 5. & \begin{tabular}{c} 
Abstract Logos \\
\hdashline \\
$\begin{array}{c}\text { Bakrie \& } \\
\text { Brothers }\end{array}$
\end{tabular} & $\begin{array}{l}\text { Logo yang dapat } \\
\text { menimbulkan } \\
\text { beraneka kesan, yang } \\
\text { dipengaruhi oleh daya } \\
\text { pemahaman } \\
\text { konsumen. Ini terjadi } \\
\text { karena bentuk visual } \\
\text { logo ini sangat abstrak. } \\
\text { Diantaranya } \\
\text { mengambil suatu } \\
\text { bentuk struktural yang } \\
\text { dikreasikan dengan } \\
\text { efek optis yang } \\
\text { bervariasi. }\end{array}$ \\
\hline
\end{tabular}

Sumber : Darmadi, 2015 


\section{d. Aspek Logo}

Pembuatan logo, harus memenuhi beberapa aspek yang harus diperhatikan dalam pembuatan logo. Menurut Kusrianto (2006) ada beberapa aspek tentang pembuatan logo yang baik yaitu :

a. Original dan distinctive. Bisa disebut mempunyai ciri khas, unik, mempunyai daya pembeda yang jelas dengan logo lain.

b. Legible: dapat di baca atau dilihat dengan jelas, saat diaplikasikan pada media.

c. Simple atau sederhana: mudah dimengerti dan dipahami.

d. Memorable: dapat diingat karena memiliki suatu keunikan, atau ciri khusus.

e. Easy associated with the company: logo yang menggambarkan citra jenis usaha atau organisasi.

f. Easily adabtable for all graphic mudah dipalikasikan, dan diterapkan dengan baik dalam bentuk fisik, warna, maupun konfigurasi [4]

\section{METODE KEGIATAN}

Metode yang digunakan dalam penelitian ini adalah metode penelitian kualitatif dimana peneliti melakukan pendekatan untuk me mperoleh data dengan cara wawancara kepada pemilik UKM Viora untuk mengetahui permasalahan, dan juga mendaptkan data untuk nantinya diberikan solusi untuk permasalahan UKM tersebut.

Langkah dalam pendekatan kualitatif pada bagan diatas adalah sebagai berikut :

1. Mengidentifikasi permasalahan yang dihadapi UKM Viora terkait logo sebagai identitas UKM Viora.
2. Pencarian data berguna untuk mencari referensi tentang desain logo-logo.

3. Proses desain awal yang meliputi :
a. Desain Alternatif
b. Desain Final

4. Proses produksi meliputi proses pemubatan output dari logo tersebut.

5. Pengaplikasian logo merupakan pengaplikasian logo baru yang telah dibuat ke produk UKM Viora.

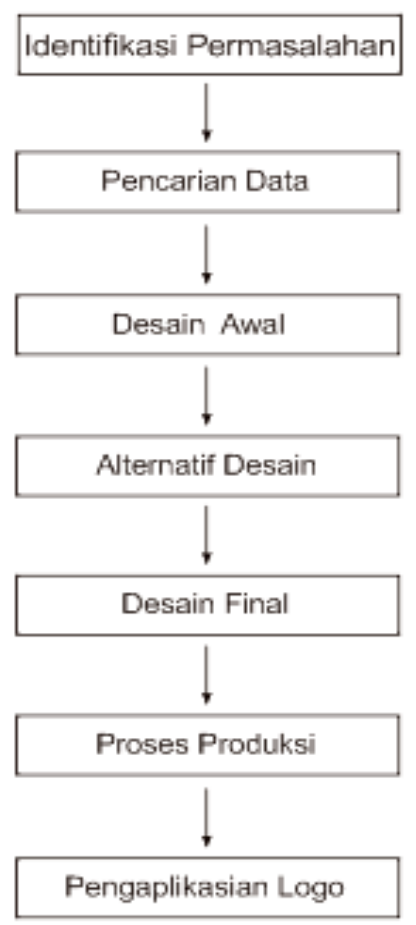

Gambar 1 Bagan alur penelitian

\section{KARYA UTAMA}

\section{Identifikasi Awal}

Pada tahapan awal program ini adalah dengan melakukan survey ke UKM Viora, untuk mengajukan beberapa usulan nama untuk logo baru. Berikut ini adalah usulan nama dari logo yang akan dibuat :

Tabel 1. Usulan Nama untuk Logo Baru UKM Viora 


\begin{tabular}{|c|c|c|}
\hline No. & Gambar & Keterangan \\
\hline 1. & LAVIORA & $\begin{array}{l}\text { Pada desain nomor } 1 \\
\text { dengan nama "LA- } \\
\text { VIORA" yang diambil } \\
\text { dari Bahasa Spanyol } \\
\text { dengan arti "LA" yang } \\
\text { arti nya "Itu" dan } \\
\text { "VIORA" sendiri yang } \\
\text { diambil dari nama awal } \\
\text { UKM Mitra. Sehingga } \\
\text { "LA-VIORA" memiliki } \\
\text { arti "Itu Viora" }\end{array}$ \\
\hline 2. & SR/IOR A & $\begin{array}{l}\text { Pada desain nomor } 2 \\
\text { dengan } \\
\text { "SAVIORA" nama } \\
\text { berasal dari gabungan } \\
\text { kata "SAVIOR" dari } \\
\text { Bahasa Inggris yang } \\
\text { berarti "Penyelamat" } \\
\text { dan "VIORA" sendiri } \\
\text { dengan makna "Viora } \\
\text { sang penyelamat" atau } \\
\text { sebaliknya "Sang } \\
\text { PenyelamatVIORA" }\end{array}$ \\
\hline 3. & R3VI0R & $\begin{array}{l}\text { Pada gambar nomor } 3 \\
\text { dengan nama } \\
\text { "R3VIORA" yang } \\
\text { terdiri dari beberapa } \\
\text { bacaan dan makna : } \\
\text { - "R3VIORA" dibaca } \\
\text { "REVIORA" dari } \\
\text { Bahasa Portugis yang } \\
\text { berarti "Ulasan, } \\
\text { Apresiasi, Telaah" } \\
\text { - Dan "R3VIORA" } \\
\text { yang dibaca "R3" + } \\
\text { "VIORA" yang berarti } \\
\text { R3 nomor blok rumah } \\
\text { Mitra yaitu Blok } \\
\text { R3/nomor } 37\end{array}$ \\
\hline
\end{tabular}

Sumber : Dokumentasi Pribadi

Setelah membuat alternatif nama yang akan dijadikan logo baru UKM Viora serta melakukan diskusi dengan pemilik untuk menetukan logo mana yang akan digunakan untuk logo baru UKM Viora tersebut. Dengan melakukan wawancara dan juga konsultasi terhadap pemilik UKM Viora memilih desain ketiga dengan nama R3VIORA yang merupakan bahasa Portugis yang memiliki arti ulasan, apresiasi, dan telaah, serta pengantian huruf " $E$ " menjadi angka 3 yang memiliki arti alamat atau tempat UKM Viora tersebut yang terletak di Blok R3.

\section{Proses Pembuatan Logo}

Proses selanjutnya merupakan pengembangan desain dari nama R3VIORA untuk dijadikan logo baru dari UKM Viora tersebut. Dalam proses ini dibuat beberapa alternatif desain logo, yang nantinya alternatif tersebut dikonsultasikan ke pemilik UKM Viora untuk mengetahui logo mana yang akan dipilih oleh mitra, untuk dijadikan logo baru.

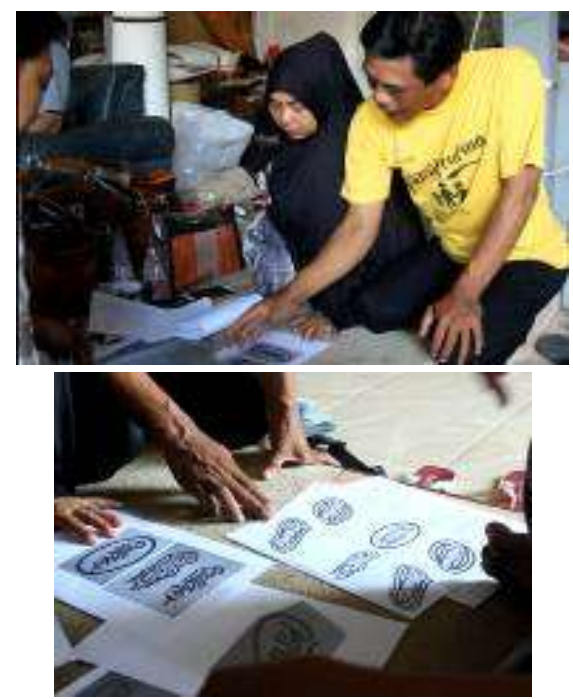

Gambar 1 Proses Konsultasi dan Wawancara Logo terhadap Pemilik UKM Viora

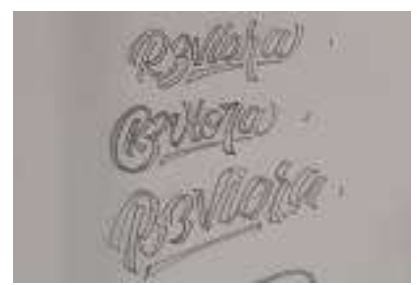




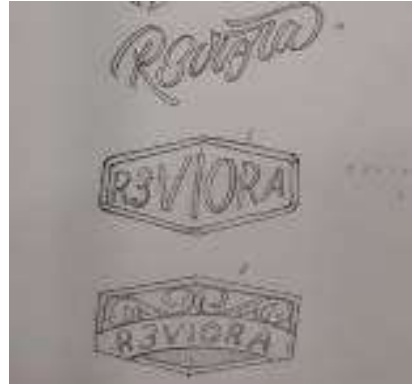

Gambar 2. Sketsa Awal Logo R3VIORA

Setelah melalui proses revisi awal, didapatkan beberapa sketsa desain alternatif baru dengan menggunakan konsep Logotype menggunakan teknik handlettering, handlettering adalah salah satu teknik kaligrafi yang lebih ke arah eksplorasi/ menggambar huruf, handlettering dibagi menjadi beberapa macam/tipe yaitu Brush Calligraphy, Script Calligraphy, Victorian Style dan Lady Style. Jadi dengan menggunakan teknik handlettering kita bisa lebih banyak mendapatkan model dari satu huruf, seperti huruf A yang divariasi sedemikian rupa.

Salah satu ciri khas dari yang diinginkan oleh mitra sendiri yaitu handlettering dengan tipe Brush Callygraphy dan Script Callygraphy. Dan pada logo R3-Viora ini, menggunakan Script Callygraphy. Kemudian didapatkan beberapa alternatif logotype dari R3-Viora dengan menggunakan teknik Script Callygraphy.

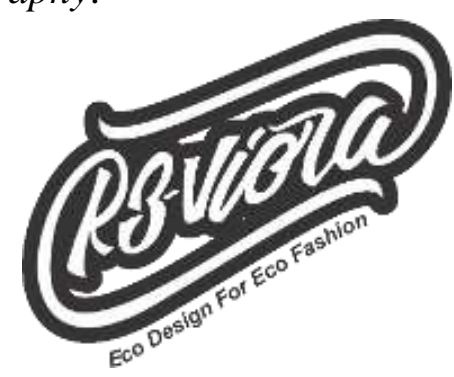

Gambar 3. Alternatif Logo 1

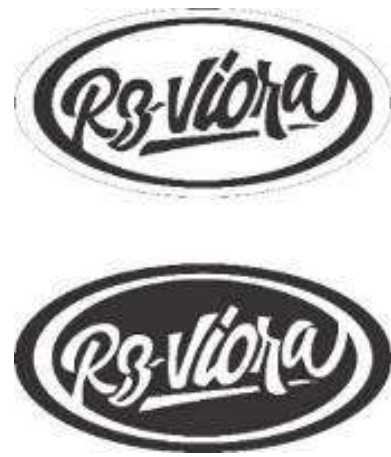

Gambar 4. Alternatif Desain 2

Setelah melalui beberapa alternatif desain dan dipresentasikan kepada pemilik UKM Viora dan melalui beberapa saran, didapatkan satu desain final yaitu dengan penambahan tulisan " Collection " pada bagian bawah R3-Viora menjadi R3-Viora Collection.

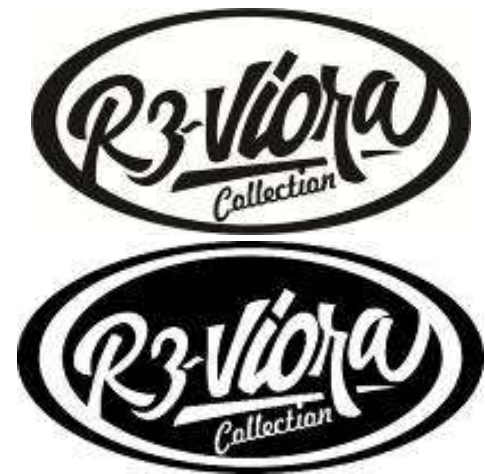

Gambar 5. Logo Terpilih Bentuk Positif (Atas), Logo Terpilih Bentuk Negatif (Bawah)

Dari gambar desain logo terpilih diatas memiliki maksud memberikan kesan dinamis karena memiliki bentuk elips atau lonjong, itu dikarenakan pemilik UKM Viora tetap ingin menambahkan unsur elips pada logonya sehingga unsur logo sebelumnya masih ada dan tetap melekat. Dan dibuat kedalam model positif dan negatif yang nantinya akan diaplikasikan kedalam berbagai media yang berkaitan dengan usaha yang dimiliki oleh UKM Viora, diantaranya stempel, label, dan lain sebagainya. 


\section{Tahap Pengaplikasian Logo}

Proses selanjutnya setelah logo final telah dipilih adalah pengaplikasian logo tersebut ke berbagai media. Yang pertama adalah pembuatan Stampel, dimana sebuah stampel ini sangat diperlukan bagi setiap pelaku usaha, instansi atau organisasi. Karena UKM Viora sudah setuju dengan logo dan nama baru maka media pertama yang menerapkan logo baru adalah stampel.
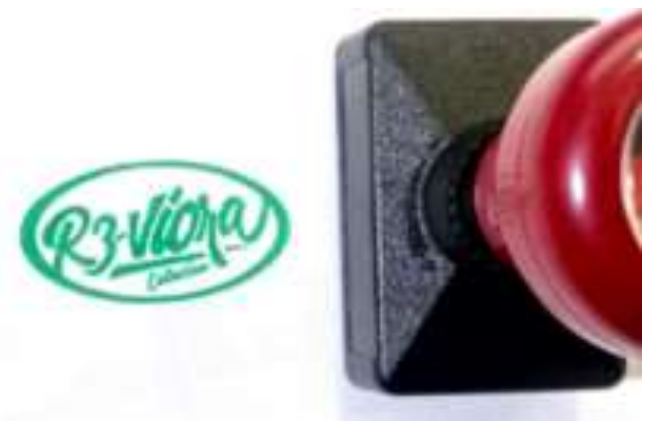

Gambar 6. Penerapan logo baru pada media stampel

Tahap Kedua yaitu mengaplikasikan logo baru ke media Label, dalam hal ini label yang diminta oleh UKM Viora adalah label yang dapat diaplikasikan ke dalam produk tas, dompet, dan souvenir yang selama ini dibuat tidak pernah menyematkan labelnya. Terdapat berbagai jenis teknik dalam pembuatan label serta berbagai jenis untuk bahan dalam pembuatan label ini, kemudian dipilih label dengan teknik laser grafir pada bahan kulit sintetis yang jadi bahan yang paling sering dipakai oleh UKM Viora. Teknik laser grafir yang dipakai menerapkan dua jenis logo terpilih diatas yaitu logo berbentuk positif dan logo berbentuk negatif.

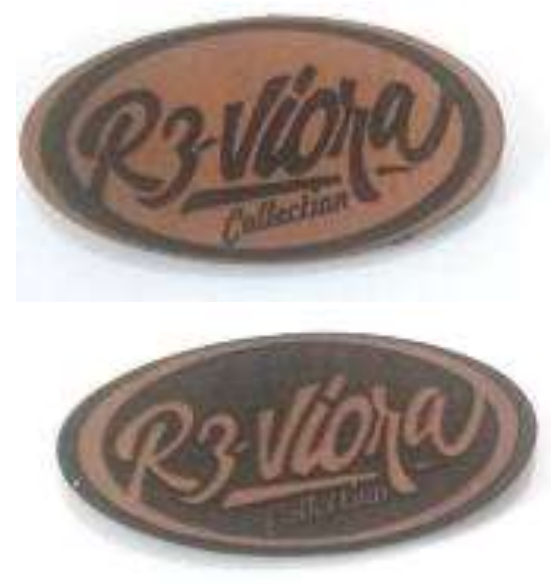

Gambar 7. Aplikasi Logo Baru melalui media label dengan teknik laser dan bahan kulit sintetis
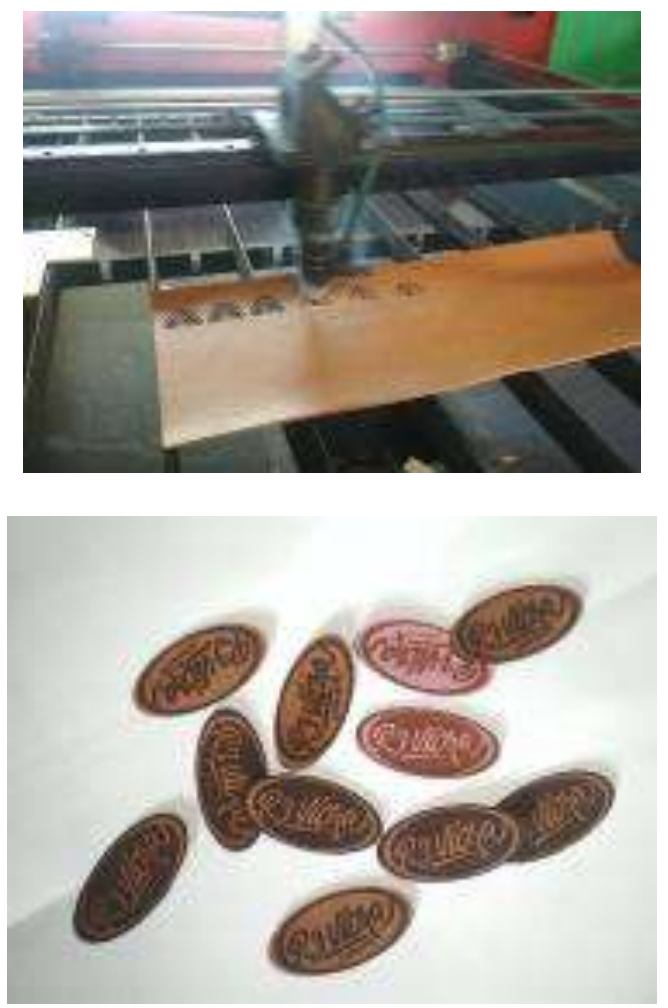

Gambar 8. Proses grafir dengan mesin laser (Atas), Hasil grafir (Bawah)

Setelah proses pembuatan label dengan teknik laser grafir, label bisa langsung diaplikasikan pada produk UKM Viora tersebut. Berikut ini pengaplikasian logo baru : 
Tabel 2. Hasil pengaplikasian logo baru

\begin{tabular}{|l|l|l|}
\hline No. & \multicolumn{1}{|c|}{ Keterangan } \\
\hline 2. & $\begin{array}{l}\text { Pengaplikasian } \\
\text { Label pada produk } \\
\text { tas jenis totebag } \\
\text { yang simpel casual } \\
\text { menambah daya jual } \\
\text { pada produknya }\end{array}$ \\
\hline 3. & $\begin{array}{l}\text { Pengaplikasian } \\
\text { Label baru pada } \\
\text { produk tas jenis } \\
\text { dompet. }\end{array}$ \\
\hline 4. & $\begin{array}{l}\text { Pengaplikasian } \\
\text { Label baru pada } \\
\text { produk dompet } \\
\text { wanita. }\end{array}$ \\
\hline $\mathbf{5 .}$ & $\begin{array}{l}\text { Pengaplikasian } \\
\text { Label baru pada } \\
\text { produk tas jenis } \\
\text { clutch. }\end{array}$ \\
\hline $\begin{array}{l}\text { Pengaplikasian } \\
\text { Label baru pada } \\
\text { produk tas wanita. }\end{array}$ \\
\hline
\end{tabular}

Sumber : Dokumentasi Pribadi

\section{ULASAN KARYA}

Hasil dari proses pembuatan Logo dan nama baru UKM Viora ini mempunyai keunggulan tersendiri yaitu :

1. Dengan bentuk Elips, Logo Mudah diaplikasikan ke berbagai media sesuai dengan kebutuhan UKM maupun kebutuhan pasar

2. Logo tetap terlihat jelas walaupun dengan berbagai macam mode yaitu mode negatif maupun mode positif

3. Logo yang dibuat secara langsung bersama UKM sehingga terjalin komunikasi antara kedua belah pihak

\section{DAMPAK DAN MANFAAT KEGIATAN}

Adanya program pengabdian kepada masyarakat ini memberikan dampak serta manfaat kepada Mitra atau UKM khususnya UKM Viora dengan pembuatan logo dan nama baru ini, adapun dampak serta manfaat yang diterima secara langsung yaitu :

1. Mitra dapat mendaftarkan merk dan identitasnya secara sah dan tidak ada penolakan kembali atas permohonan identitas barunya.

2. Mitra dapat menyematkan Logo barunya di setiap produk yang akan dibuat, sehingga merasa lebih aman dan tidak ditiru oleh konsumen atau pengusaha lain.

3. Mitra lebih leluasa untuk memperkenalkan lebih luas usahanya kepada masyarakat umum, atau para pelanggannya.

4. Mitra dapat meningkatkan jenis variasi produknya dengan inspirasi dari logo dan nama baru tersebut.

\section{KESIMPULAN}

Dari hasil program pengabdian ini dapat disimpulkan bahwa hasilnya adalah merancang logo baru untuk UKM Viora dan dapat diaplikasikan ke berbagai media. Perancangan logo baru ini didasarkan pada permasalahan yang dialami UKM Viora. Dari permasalahan yang dialami oleh UKM Viora tersebut maka muncullah solusi desain logo baru UKM Viora yaitu R3VIORA yang merupakan bahasa Portugis yang memiliki arti ulasan, apresiasi, dan telaah, serta pengantian huruf "E" menjadi angka 3 yang memiliki arti alamat atau tempat 
UKM Viora tersebut yang terletak di Blok R3. Logo baru ini menggunkan handlettering dengan tipe Brush Callygraphy dan Script Callygraphy. Dan pada logo R3-Viora ini, desainer menggunakan Script Callygraphy. Untuk pengaplikasian logo baru digunakan pada stampel, dan juga dijadikan label produk dari UKM Viora.

\section{DAFTAR PUSTAKA}

[1]. Choirul Anam, L. H. Nugraha, Rochman A.N. (2018). Pemanfaatan Kantong Semen dan Kayu Laser Sebagai Produk Tas untuk Meningkatkan Kreatifitas dan Nilai Jual di UKM Viora Tanggulangin, Sidoarjo. Jurnal ITENAS Rekarupa, Vol. 05 No. 1, page 11-21

[2]. Dasril A., Syafwandi, Faisal D. (2017). Perancangan Corporate Identity Distro Reckless Store Padang. Jurnal Universitas Negeri Padang, Vol. 05, No. 2

[3]. Hidayat A., (2017) Perancangan Buku Panduan Teknik Brush Calligraphy Script. Skripsi thesis,
Repository Institut Seni Indonesia Yogyakarta.

[4]. Nugroho, S. (2015). Manajemen Warna Dan Desain (hal. 182). Yogyakarta: ANDI.

[5]. Satria Apriandi, A. S. (2018). Hand Lattering Karya Awaludin. Jurnal Seni Rupa, Volume 06 Nomor 01. Universitas Negeri Surabaya.

[6]. Wong, W. (1986). Beberapa Asas Merancang Dwimatra. Bandung: ITB.

[7]. Sudharmono, B., Firmansyah, E. (2019). Tersedia pada: https:/Error! Hyperlink reference not valid.. [Diakses : 10 Mei 2019]. Program Studi Teknik Informatika STMIK Sumedang

[8]. Team-de.blogspot.com. Tersedia pada: https://team-de.blogspot.com/ 2014/12/pengertian-nirmanadwimatra-atau.html [Diakses : $10 \mathrm{Mei}$ 2019]. 